\title{
THE IMPORTANCE OF MOVEMENT AND HEALTHY LIVING IN YOUNG PEOPLE
}

\author{
Vaida Marius \\ Petroleum - Gas University of Ploiești
}

\begin{abstract}
The study I have carried out aimed mainly the determination of the level of the motion perception and its benefits, but also the understanding of the manner in which leisure time is spent and the raise of awareness regarding the importance of healthy eating in daily lives. The research was carried out on a sample of 50 young people (boys and girls) aged between 19 and 30. The main method of research used was the investigation, which was based on an anonymous standardized questionnaire with 8 questions. The study shows that the main effect young people have perceived for having a sport activity is the development of physical condition followed by tackling of the excessive weight and alsothe maintainance of an optimal muscle tone, as well as the education of the positive characteristics of the personality and the extention of the skills andmotor skills sphere to an equal but small value.They also confirmed that sports accompanied by friends or colleagues is preffered for leisure time, food also being perceived as very important or important in a majoritarian percentage, meaning that the younger generation is aware of the important role of nutrition in maintaining health. Unfortunately, however, it is clear that there is no regular physical activity in those surveyed, with the results of those who are adherents of regular physical activity slightly below the results of those who do not practice regular forms of activity.
\end{abstract}

Keywords:motion, health, lifestyle, young people

\section{Intoduction}

The study I have carried out aimed mainly the determination of the level of the motion perception and its benefits, but also the understanding of the manner in which leisure time is spent and the raise of awareness regarding the importance of healthy eating in daily lives.

Modern man must have a multilateral development, translating into an intellectual, esthetic, physical development etc. The development ofhis physical capacity and also the improvement and expansion of the motor skills and skills in general is a priority for today's young people, because the temptations are many more than for previous generations when there were no smarphones etc.

Normally everyone should be concerned about their own health, their working capacity, but also their lifestyle.

The proper combination of work, movement, rest and diet can only lead to a healthy lifestyle, this is also reflected in the increase of the life expectancy of the population. Man generally considers that being healthy is normal and maybe they don't have to approach an ordinary healthy lifestyle etc., and there is a possibility that later on the lack of movement, healthy eating and stress, etc. might pose health problems for the individual, but this can be avoided by prevention.

The human development process is also considered to be influenced by the human potential for physical activity which regresses, adapts or refines to different variables. 
E. Hahn (1996, p. 50)by approaching this sport problem in children, he evidentiated that "the effects generated by modern lifestyle, due to urbanization and interdictioms, limits the need for children to do activities, the lack of logical motivation for physical activity in schools and for children's health, are all the problems that, in order to be resolved, require intense and constant efforts. The very structures of sport are largely responsible for this. Sport, too early and reckless, inspired by the adult model, has often not been adapted to the level and needs of children".

\section{Materials and methods}

The research was carried out on a sample of 50 young people (boys and girls) aged between 19 and 30.The main method of research used was the investigation, which was based on an anonymous standardized questionnaire with 8 questions.

The questionnaire had only one response out of 3 or multiple answers. Other research methods used in this study were: bibliographic study method, statistical data processing and the graphical method.

\section{Results}

The first item

is related to the question: "What effects do you think sport has had on you?", and has five options for answer as follows: development ofthe physical condition, maintainance of an optimal muscle tone, education on the positive personality traits, combat of overweight, extending the range of skills and motor skills.

Table 1. Values resulted from the processing of item 1

\begin{tabular}{|c|c|c|c|c|c|c|c|c|c|c|c|c|}
\hline \multirow[t]{3}{*}{$\begin{array}{c}\text { Item } \\
1 .\end{array}$} & \multicolumn{2}{|c|}{$\begin{array}{l}\text { Physical } \\
\text { condition }\end{array}$} & \multicolumn{2}{|c|}{$\begin{array}{l}\text { Maintenance } \\
\text { of optimal } \\
\text { muscle tone }\end{array}$} & \multicolumn{2}{|c|}{$\begin{array}{c}\text { Education } \\
\text { on the } \\
\text { positive } \\
\text { personality } \\
\text { traits }\end{array}$} & \multicolumn{2}{|c|}{$\begin{array}{l}\text { Combat of } \\
\text { overweight }\end{array}$} & \multicolumn{2}{|c|}{$\begin{array}{l}\text { Expanding } \\
\text { the sphere } \\
\text { of skills } \\
\text { and motor } \\
\text { skills }\end{array}$} & \multicolumn{2}{|c|}{ Total } \\
\hline & $N r$. & $\%$ & $N r$. & $\%$ & $N r$. & $\%$ & $N r$. & $\%$ & $N r$. & $\%$ & $N r$. & $\%$ \\
\hline & 28 & 28 & 20 & 20 & 13 & 13 & 26 & 26 & 13 & 13 & 100 & 100 \\
\hline
\end{tabular}

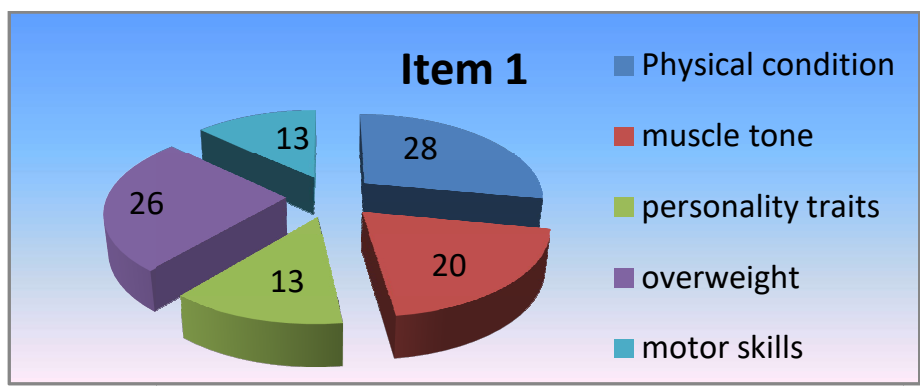

Graph1.The percentage values of the data item 1

At this point you can see relatively close percentages for three of the variants and equality for two variants chosen by the subjects. The highest result is for the development of the physical condition with $28 \%$, followed by the $26 \%$ which represents the tackling of the weight excess and the maintenance of an optimal muscle tone with $20 \%$. The last two variants had equal percentage values $(13 \%)$ and are represented by theeducation on the positive personality traits and the expansion of the range of skills and motor skills.

The second item in the questionnaire was associated with the following statement: "Within the physical sports activity of leisure you participate most often with:". The options were as follows: friends, alone, colleagues, family members or it doesn't matter. 
Table 2. Values resulted from the processing of item 2

\begin{tabular}{|c|c|c|c|c|c|c|c|c|c|c|c|c|}
\hline \multirow{2}{*}{$\begin{array}{c}\text { Item } \\
2 .\end{array}$} & \multicolumn{2}{|l|}{ Friends } & \multicolumn{2}{|c|}{ Alone } & \multicolumn{2}{|c|}{ Colleagues } & \multicolumn{2}{|c|}{$\begin{array}{c}\text { Family } \\
\text { members }\end{array}$} & \multicolumn{2}{c|}{$\begin{array}{c}\text { Does not } \\
\text { matter }\end{array}$} & \multicolumn{2}{|c|}{ Total } \\
\cline { 2 - 14 } & $N r$. & $\%$ & $N r$. & $\%$ & $N r$. & $\%$ & $N r$. & $\%$ & $N r$. & $\%$ & $N r$. & $\%$ \\
\cline { 2 - 14 } & 37 & 37 & 19 & 19 & 21 & 21 & 12 & 12 & 11 & 11 & 100 & 100 \\
\hline
\end{tabular}

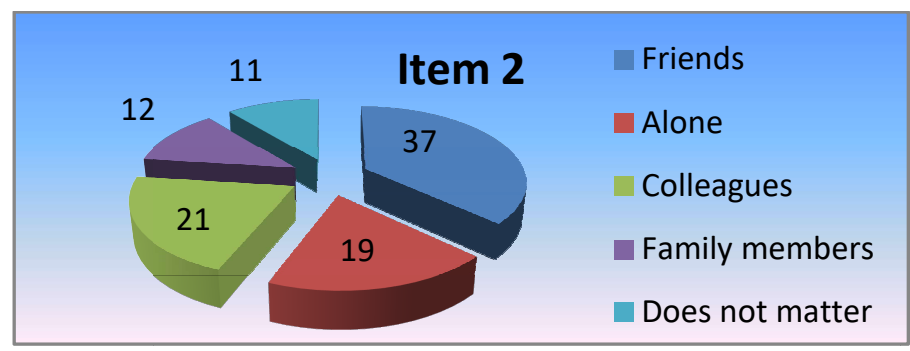

Graph 2. The percentage values of the data item 2

The data collected from this question shows that the vast majority of young people prefer to do physical activities with friends (37\%) or colleagues $(21 \%)$, followed by those who exercise alone $(19 \%)$, with the family $(12 \%)$ or the ones for whom doesn't matter who they exercise with, where the percentage is $11 \%$ doesn't matter.

The third item in the questionnaire relates to the question: "How do you consider healthy eating in relation to regular sports activity as a form of health maintenance?". The answers to this item are four: very important, important, not important and I do not know. In table and graph3, I present the results obtained at this item.

Table 3. Values resulted from the processing of item 3

\begin{tabular}{|c|c|c|c|c|c|c|c|c|c|c|}
\hline \multirow{2}{*}{$\begin{array}{c}\text { Item } \\
3\end{array}$} & \multicolumn{2}{|c|}{$\begin{array}{c}\text { Very } \\
\text { important }\end{array}$} & \multicolumn{2}{|c|}{ Important } & \multicolumn{2}{c|}{ Unimportant } & \multicolumn{2}{c|}{$\begin{array}{c}\text { I do not } \\
\text { know }\end{array}$} & \multicolumn{2}{c|}{ Total } \\
\cline { 2 - 11 } & $N r$. & $\%$ & $N r$. & $\%$ & $N r$. & $\%$ & $N r$. & $\%$ & $N r$. & $\%$ \\
\cline { 2 - 11 } & 49 & 49 & 37 & 37 & 6 & 6 & 8 & 8 & 100 & 100 \\
\hline
\end{tabular}

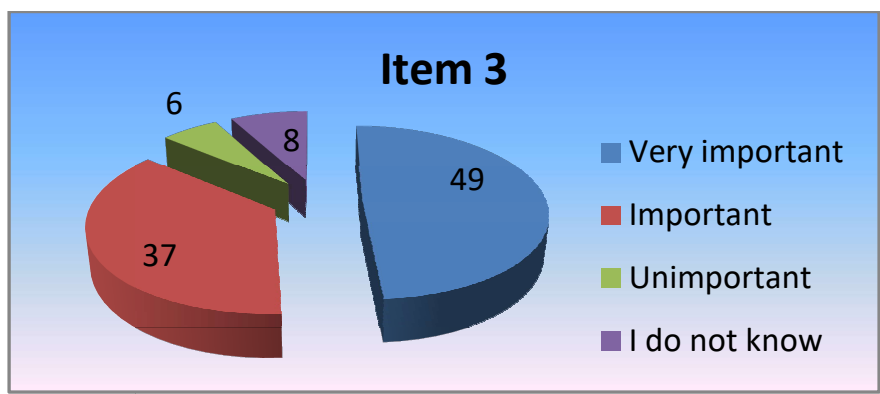

Graph3 .The percentage values of the data item 3

Item 3 is characterized by the fact that $49 \%$ of the responses consider healthy eating reporting to regular sports activity a very important form of health maintenance, $37 \%$ of the subjects considered healthy eating to be important for health, $6 \%$ responded negatively and $8 \%$ were undecided.

The fourth item concerns the question: "Do you think that financial status influences the opportunity to do a particular sport (even mass sports)?". The responses received are presented in table and graph 4.

Table 4. Values resulted from the processing of item 4

\begin{tabular}{|c|c|c|c|c|c|c|c|c|}
\hline \multirow{2}{*}{$\begin{array}{c}\text { Item } \\
4 .\end{array}$} & \multicolumn{2}{|c|}{ Yes } & \multicolumn{2}{c|}{ No } & \multicolumn{2}{c|}{$\begin{array}{c}\text { I do not } \\
\text { know }\end{array}$} & \multicolumn{2}{c|}{ Total } \\
\cline { 2 - 8 } & $N r$. & $\%$ & $N r$. & $\%$ & $N r$. & $\%$ & $N r$. & $\%$ \\
\hline
\end{tabular}




\begin{tabular}{|l|l|l|l|l|l|l|l|l|}
\hline & 38 & 38 & 41 & 41 & 21 & 21 & 100 & 100 \\
\hline
\end{tabular}

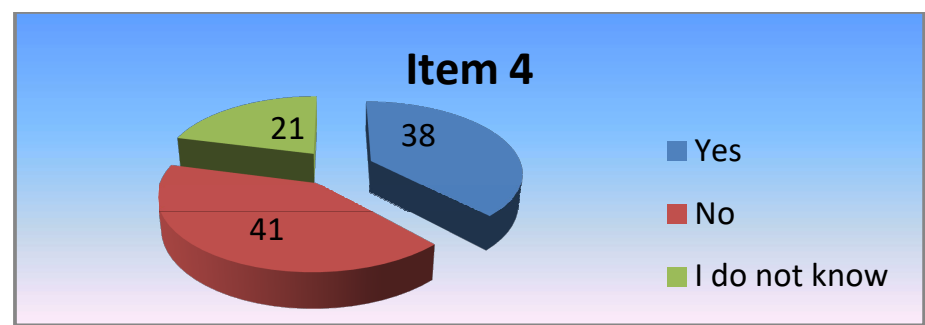

Graph4 .The percentage values of the data item 4

The evidence shows that there is some balance between responses, with a majority (41\%) saying that financial status does not influence the opportunity to do a sport, with $38 \%$ agreeing that the financial status influences the opportunities and $21 \%$ saying that they do not know.

Item 5 corresponds to the question: "Do you think any current or former romanian athlete might be a model for you?". The answers to this item are three: yes, no, I do not know. In table and graph5, I present the results obtained at this item.

Table 5. Values resulted from the processing of item 5

\begin{tabular}{|c|c|c|c|c|c|c|c|c|}
\hline \multirow{2}{*}{$\begin{array}{c}\text { Item } \\
5 .\end{array}$} & \multicolumn{2}{|c|}{ Yes } & \multicolumn{2}{c|}{ No } & \multicolumn{2}{c|}{$\begin{array}{c}\text { I do not } \\
\text { know }\end{array}$} & \multicolumn{2}{c|}{ Total } \\
\cline { 2 - 9 } & $N r$. & $\%$ & $N r$. & $\%$ & $N r$. & $\%$ & $N r$. & $\%$ \\
\cline { 2 - 9 } & 33 & 33 & 29 & 29 & 38 & 38 & 100 & 100 \\
\hline
\end{tabular}

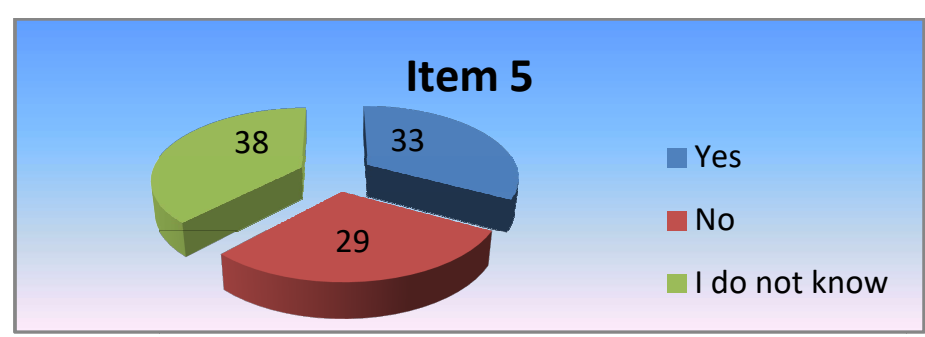

Graph5 . The percentage values of the data item 5

Item 5 is characterized by a majority of values of " I do not know" (38\%), followed by positive $(33 \%)$ and $29 \%$ negative responses.

The sixth item refers to "How much time you spend on the internet every day, social media, games, tv etc". This refers to the temptations of the modern world, with young people today being the most exposed to these temptations. The answers to this item are four: less than 1 hour, 1-2 hours, 3-4 hours, more than 4 hours. The results achieved can be seen in the table and graph below.

Table 6. Values resulted from the processing of item 6

\begin{tabular}{|c|c|c|c|c|c|c|c|c|c|c|}
\hline \multirow{2}{*}{$\begin{array}{c}\text { Item } \\
6 .\end{array}$} & \multicolumn{2}{|c|}{$<\mathbf{1}$ Hour } & \multicolumn{2}{|c|}{$\mathbf{1 - 2}$ hours } & \multicolumn{3}{c|}{$\mathbf{3 - 4}$ hours } & \multicolumn{2}{c|}{$>\mathbf{4}$ hours } & \multicolumn{2}{|c|}{ Total } \\
\cline { 2 - 11 } & $N r$. & $\%$ & $N r$. & $\%$ & $N r$. & $\%$ & $N r$. & $\%$ & $N r$. & $\%$ \\
\cline { 2 - 12 } & 16 & 16 & 27 & 27 & 34 & 34 & 23 & 23 & 100 & 100 \\
\hline
\end{tabular}




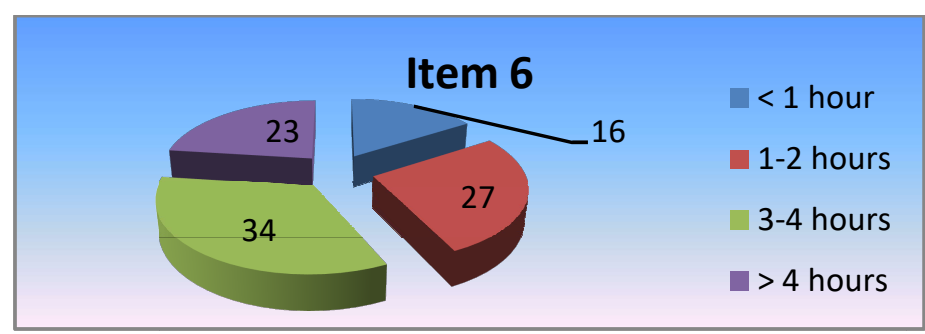

Graph 6 .The percentage values of the data item 6

The fact that the vast majority of young people are losing a lot of time on the Internet, social media, etc. is also demonstrated by the values shown above, with $34 \%$ of young people who spend up to 3-4 hours a day on the phone, computer, etc.

Item 7 is intended to determine whether the younger generation is an adept of regular physical activity. At this point the answers are: yes, no, I do not know.

Table 7. Values resulted from the processing of item 7

\begin{tabular}{|c|c|c|c|c|c|c|c|c|}
\hline \multirow{2}{*}{$\begin{array}{c}\text { Item } \\
7 .\end{array}$} & \multicolumn{2}{|c|}{ Yes } & \multicolumn{2}{c|}{ No } & \multicolumn{2}{c|}{$\begin{array}{c}\text { I do not } \\
\text { know }\end{array}$} & \multicolumn{2}{c|}{ Total } \\
\cline { 2 - 9 } & $N r$. & $\%$ & $N r$. & $\%$ & $N r$. & $\%$ & $N r$. & $\%$ \\
\cline { 2 - 9 } & 43 & 43 & 48 & 48 & 9 & 9 & 100 & 100 \\
\hline
\end{tabular}

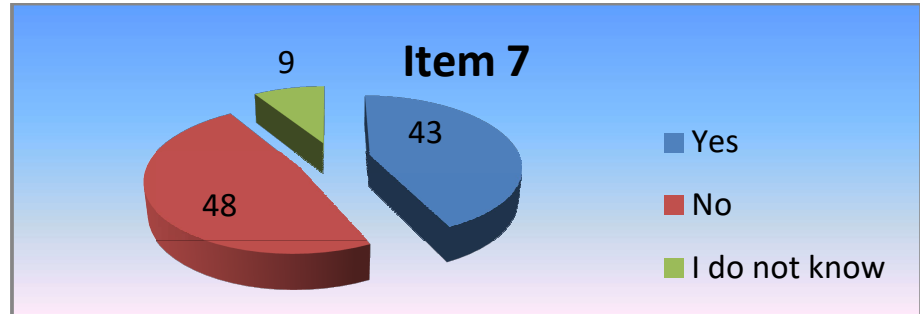

Graph7 .The percentage values of the data item 7

The answers to this question highlight the fact that, at a percentage relatively close to those practice regular physical activities, those who do not practice regular movement are $48 \%$, higher than $43 \%$.

The last item refers to physical education and corresponds to the question: "Do you think physical education is important for your development?". The answers of this item are: yes, no, I do not know.

Table 8. Values resulted from the processing of item 8

\begin{tabular}{|c|c|c|c|c|c|c|c|c|}
\hline \multirow{2}{*}{$\begin{array}{c}\text { Item } \\
8 .\end{array}$} & \multicolumn{2}{|c|}{ Yes } & \multicolumn{2}{c|}{ No } & \multicolumn{2}{c|}{$\begin{array}{c}\text { I do not } \\
\text { know }\end{array}$} & \multicolumn{2}{c|}{ Total } \\
\cline { 2 - 9 } & $N r$. & $\%$ & $N r$. & $\%$ & $N r$. & $\%$ & $N r$. & $\%$ \\
\cline { 2 - 9 } & 51 & 51 & 27 & 27 & 22 & 22 & 100 & 100 \\
\hline
\end{tabular}

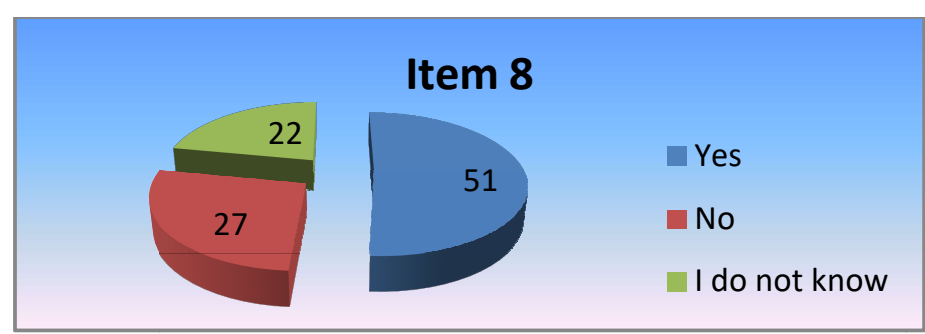

Graph8 . The percentage values of the data item 8

The majority of the answers were positive answers (51\%), to the question of whether physical education is important for the personal development of sthe ubjects, which shows that they are aware of the importance of the movement. 


\section{Conclusions}

The study shows that the main effect young people have perceived based on practising sport activities is the development of physical condition followed by tackling of the excessive weight and also the maintainance of an optimal muscle tone, followed by the education on the positive features of the personality and the expansion of the sphere of skills and motor skills to an equal but small score in value.

They also confirmed that leisure is preferred for sports thatcan be accompanied by friends or colleagues, with food being perceived as very important or important in a majoritarian percentage, meaning that the younger generation is aware of the important role of nutrition in maintaining health.

Unfortunately, however, it is clear that there is no regular physical activity in those surveyed, with the results of those who practice regular physical activity slightly below the results of those who do not practice regular forms of motion. However, the financial status of young people is not considered to be an impediment to a given sport, and there are many options for doing cheap or free activities (bicycle walks, running in the park, etc).

The fact that the number of hours that young people spend on the Internet, social media, games, tv etc. is quite high, especially during holidays, means that there are high temptations, negatively influencing the time available for doing sport.

The results show that most young people surveyed acknowledge that physical education is important for personal development, which is gratifying in the context of the steady rise of the time-consuming "temptations".

\section{REFERENCES}

1. Bompa, T., 2001, Dezvoltarea calităţilor biomotrice - Periodizarea, Ediţie şi traducere în limba română, CNFPA, Edit. Ex Ponto, Bucureşti.

2. Bota, C., 2000, Ergofiziologie, Edit. Globus, Bucureşti.

3. Bota, C., 2002, Fiziologie generală. Aplicaţii la efortul fizic, Edit. Medicală, Bucureşti.

4. Cristea, E., 1990, Terapia prin mișcare la vârsta a treia, Edit. Medicală, București.

5. Dragan, I., 1982, Medicinaspotiva, Editura Sport - Turism, Bucuresti.

6. Dumitru, Gh,, 1997, Sănătate prin sport pe înțelesul fiecăruia, Federaţia Română Sportul pentru Toți, Bucuresti.

7. Hahn, E. (1996). Antrenamentul sportiv la copii. Bucureşti: SCJ, 104-105 (3-4), CCPS.

8. Pop, C., 2014, Student's Satisfaction - An Indicator of Quality in Physical Education. Revista Romaneasca pentru Educatie Multidimensionala, Volume 6, Issue 1, p. 89.http://revista romaneasca.ro/wp-content/uploads/2014/07/REV_June2014_83to92.pd

9. Suciu, A., Dumitru, Gh., 1999, Ghid pentru sănătate și condiție fizică, Federația Română Sportul pentru Toți, Bucuresti.

10. https://dokumen.tips/documents/chestionar-sociologic-despre-sport.html

11. http://www.sport.pub.ro/activ_stiintifica_studenti/Sesii\%20stud\%202017/Model_cercetare_ anchet $\%$ C4\%83_chestionar.pdf

12. http://www.bpe.biz.pl/kts-k/ro/sport-4-all_ro/

13. https://freeonlinesurveys.com/s.asp?sid=33v96iz9itd9yau603528\#/0

14. https://semneletimpului.ro/sanatate/stil-de-viata/sport/cum-iti-schimba-sportul-viata.html 